\title{
Covid-19: Prayers Performance of Medical Team Without Ablution and Tayammum Based On Four Madhab Fiqh*
}

\author{
Hudzaifah Achmad Qotadah ${ }^{1}$ \\ Department of Fiqh and Usul, Acedemy of Islamic Studies, \\ University of Malaya, Malaysia \\ d \\ $\underline{10.15408 / \text { sjsbs.v7i8.15620 }}$
}

\begin{abstract}
One of the main pillars of Islam is salat, wherein obliging salat, Allah SWT raised Prophet Muhammad SAW directly to the heavens through Isra Mi'raj. Five daily prayers are obligatory duties that must be performed by every Muslim as proof of devotion, obedience, and submission to His command with its requirements and pillars. The essence of salat cannot only be seen in practice but also on its process, such as wudu. Wudu is a procedure to purify the body with water. Wudu is one of the requirements for a valid salat, which is an obligation for every Muslim. Islam is filled with blessings and ease ( $r u k h s a h)$, given by Allah SWT to His Muslim servants. If one cannot perform wudu with water, then Allah SWT gave rukhsah, which is tayammum. A problem occurs if a Muslim unable to perform both wudu and tayammum, Which the COVID-19 healthcare worker is experiencing recently. This article is intended to research the rules in performing salat without wudhu or tayammum for COVID19 healthcare workers based on four madhhab fiqh. In this research, the researcher uses a full qualitative method and documentation related to the topic of this research, which then will be analyzed descriptively.
\end{abstract}

Keywords: Salat, Wudhu, Tayammum, COVID-19, Madhab.

\begin{abstract}
Abstrak
Sepertimana diketahui bahawa salah satu daripada pokok ajaran agama ialah shalat dimana dalam mewajikan ibadah shalat, Allah SWT langsung mengangkat Nabi Muhammas SAW ke langit melalui peristiwa Isra Mi'raj. Shalat fardhu yang lima waktu merupakan ibadah maktubah yang wajib diamalkan oleh setiap hamba-Nya yang muslim sebagai bukti daripada sebuah ketaatan, kepatuhan serta ketundukan pada perintah-Nya SWT dengan syarat dan rukun yang melekat di dalamnya. Esensi ibadah shalat bukan hanya sekedar terihat dari sisi pelaksanaan shalatnya akan tetapi dilihat dari sisi mulai prosesnya ibadah shalat itu sendiri seperti berwudhu. Wudhu merupakan salah satu cara menyucikan anggota tubuh dengan air dimana wudhu menjadi salah satu syarat sahnya ibadah shalat yang mesti dilakukan oleh setiap umat muslim. Agama Islam penuh dengan keberkahan serta kemudahan (rukhsah) yang diberikan Allah SWT kepada hamba-Nya yang muslim dimana apabila berhalangan berwudhu dengan air maka Allah SWT memberikan rukhsah berupa bertayammum. Namun, bagaimana jika seorang muslim berhalangan dalam melakukan keduanya baik wudhu mahupun tayammum seperti halnya yang dirasakan baru-baru ini oleh para petugas medis COVID-19. Artikel ini bertujuan untuk meneliti bagaimana hukum melaksanakan ibadah shalat tanpa berwudhu mahupun bertayammum bagi para petugas medis COVID-19 berdasarkan kepada pandangan-pandangan madhah fiqih. Metode yang digunakan penulis dalam penelitian ini ialah dengan menggunakan metode kualitatif penuh serta data dokumentasi yang terkait dengan topik kajian penelitian ini, kemudian dianalisis secara deskriptif.

Kata-kata kunci: Shalat, Wudhu, Tayammum, COVID-19, Madhab.
\end{abstract}

* Received: April 14, 2020, Revision: May 24, 2020, Published: September 30, 2020.

${ }^{1}$ Hudzaifah Achmad Qotadah is a researcher at Departmen of Fiqh and Usul, Academy of Islamic Studies, University of Malaya, Malaysia. Email: hudzaifahachmad47@gmail.com 


\section{Introduction}

Islam has three-dimension teaching. The first dimension is Aqidah, a teaching of worshipping one god, Allah SWT, which is implemented in six articles of faith. The second dimension is Sharia, which is divided into special rituals that covers shahada, salat, zakat, fasting and haji, and muamalah that covers political and civil laws. The third dimension is moral or akhlaq, divided into two parts (akhlaq to God and akhlaq to creature such as to oneself, family, community, animal, etc.). ${ }^{2}$

Salat is one of the prayers intended to close oneself to Allah SWT. Salat is one of the most important prayers in Islam. Salat also has a particular position, for it is the most essential prayer than other prayers. ${ }^{3}$ His Revelation:

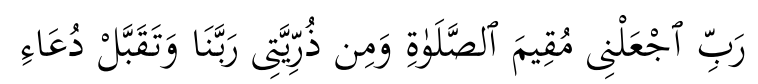

"My Lord, make me an establisher of prayer, and [many] from my descendants. Our Lord, and accept my supplication." (QS: Ibrahim: 40)

The establishment of Islam in oneself depends on one's salat performance and experience. By establishing salat, one will always receive His blessing. Salat is also the key to open heaven's door. ${ }^{4}$ Therefore, Allah SWT obligates His servant to perform salat, as stated in His Revelation:

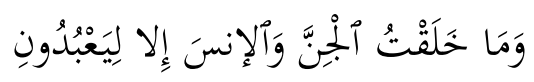

"And I did not create the jinn and mankind except to worship Me." (QS: Adh-Dariyat: 56)

The verse above has a meaning that mankind and jinn have to worship and obey Allah SWT. Salat is also a demarcation line between Muslims and non-Muslims, as stated by Muhammad SAW which said that the difference between kafir (non-Muslims) and Muslims is salat. ${ }^{5}$

Etymologically, salat came from Arabic word that means prayer ${ }^{6}$, where every word uttered when performing salat is a prayer for virtue and praise ${ }^{7}$, meanwhile salat according to syar'i of fuqaha is defined as:

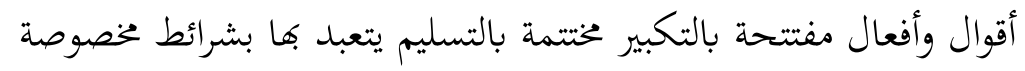

${ }^{2}$ Zaitun, Siti Habibah, Implementasi Sholat Fardhu Sebagai Sarana Pembentuk Karakter Mahasiswa Universitas Maritim Raja Ali Haji Tanjungpinang, Journal: Pendidikan Agama Islam: Ta'lim, Vol. 11, No. 2 (2013), 154.

${ }^{3}$ Shalil bin Ghanim as-Sadlan, Fiqih Shalat Berjamaah, Jakarta: Pustaka As-Sunnah, cet. 1, 2006, 30.

${ }^{4}$ Rubino, Studi Kolerasi tentang Pemahaman Pentingnya Ibadah Shalat dan Pengamalannya, Journal: Pendidikan Madrasah, Vol. 3, No. 1 (Mei 2008), 199-200.

${ }^{5}$ Deden Suparman, Pembelajaran Ibadah Shalat Dalam Perspektif Psikis dan Medis, Journal: ISTEK, Vol. 9, No. 2 (2015), 48.

${ }^{6}$ Muhammad bin Abul Abbas Ahmad bin Hamzah bin Syihabuddin al Ramli, Nihayatul Muhtaj ila Syarhil Minhaj, (Beirut: Dar al-Kutub al-Ilmiah, cet. 3, 2003), jilid 1, 358-359.

7 Zaitun, Siti Habiba, Implementasi Sholat Fardhu.... 154. 
"Some words and actions that begin with takbir and end with salam to worship Allah SWT by meeting the predetermined conditions."

In its practice, salat has conditions that validates the prayer, one of which is wudu, a direct order from Allah SWT as stated in Al-Qur'an as a way to purify one's body before performing salat. ${ }^{9}$ The definition of wudu from al-Muhith dictionary is:

$$
\text { الوضوء لغة الحسن والنظافة }
$$

Which means: beautiful and clean. ${ }^{10}$ Whereas terminologically, wudu is defined as:

$$
\text { الغسل والمستح على أعضاء مخصوصة بنية مخصوصة }
$$

Which means: wash and wipe certain parts with certain intention. ${ }^{11}$

According to Indonesia Dictionary, wudu is an act of purifying oneself before salat by washing face, forearms, part of head and feet. ${ }^{12}$ His Revelation in al-Qur'an:

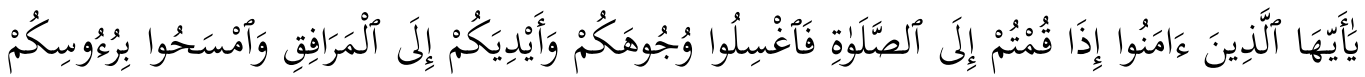

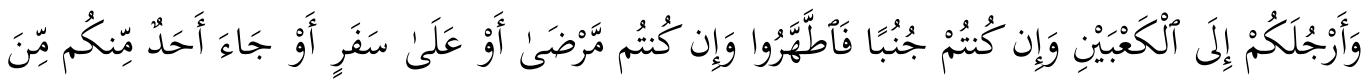

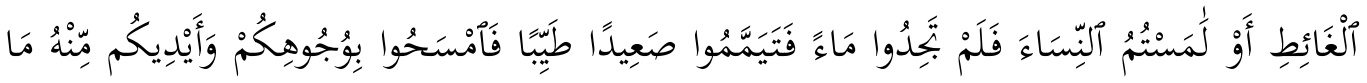

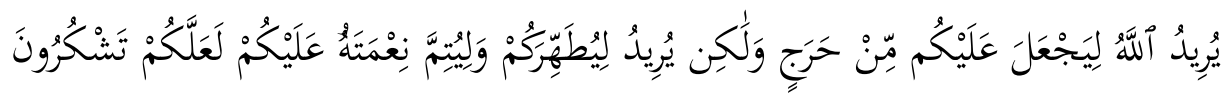

"O you who have believed, when you rise to [perform] prayer, wash your faces and your forearms to the elbows and wipe over your heads and wash your feet to the ankles. And if you are in a state of janabah, then purify yourselves. But if you are ill or on a journey or one of you comes from the place of relieving himself or you have contacted women and do not find water, then seek clean earth and wipe over your faces and hands with it. Allah does not intend to make difficulty for you, but He intends to purify you and complete His favor upon you that you may be grateful." (QS. Al-Ma'idah: 6)

This verse describes the actions need to be performed in wudu. Allah SWT stated that wudu is not intended to cause difficulty, but for the benefits on humankind. In addition, the Sharia of wudu with water as the purifier has been stated in His Revelation:

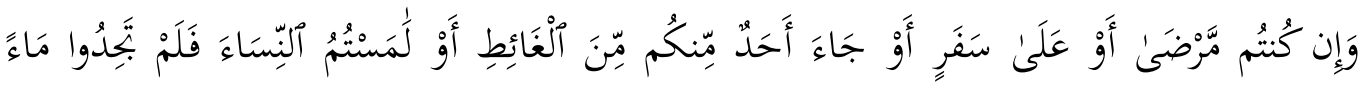

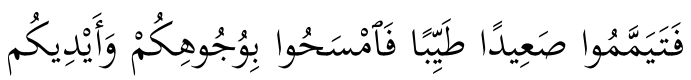

${ }^{8}$ Al Ramli, Nihayatul Muhtaj ila Syarhil Minhaj, jilid 1, 358-359.

${ }^{9}$ Lela, Luknawati, Ketenangan: Makna Dawamul Wudhu (Studi Fenomenologi Pada Mahasiswa UIN Raden Fatah Palembang), Journal: PSIKIS, Vol. 1, No, 2 (Desember 2015), 55.

${ }^{10}$ Muhammad bin Ya'qub al-Fairuzabadi, al-Qamus al-Muhith, (Beirut: Muassasah al-Risalah, cet. 8, 2005), 55. https://ia800206.us.archive.org/19/items/waq105905/105905.pdf

11 'Abdul Rauf al-Minawi, al-Tauqif 'Ala Muhimmat al-Ta'arif, tahqiq: 'Abdul Hamid Shalah Hamdan, (al-Kaherah:'Alim al-Kutub, $\quad$ cet. 338. https://ia801200.us.archive.org/10/items/tamotaPDF/tamota.pdf.

12 Kamus Bahasa Indonesia, Jakarta: Pusat Bahasa Departmen Pendidikan Nasional, cet. Xvi, 2008 1624. https://Journal:-oldi.or.id/public/kbbi.pdf, accessed on 05 April 2020, 23:11pm. 
"...And if you are ill or on a journey or one of you comes from the place of relieving himself or you have contacted women and find no water, then seek clean earth and wipe over your faces and your hands [with it]. Indeed, Allah is ever Pardoning and Forgiving." (QS: an-Nisa: 43)

This verse also describes the sharia of tayammum as an act that can replace wudu in certain conditions such as lack of water, sickness, etc. In other words, if a Muslim cannot perform wudu, Islam gives him rukhsah which is tayammum for people who cannot use water because of some limitations (udzur). The definition of tayammum is as follows:

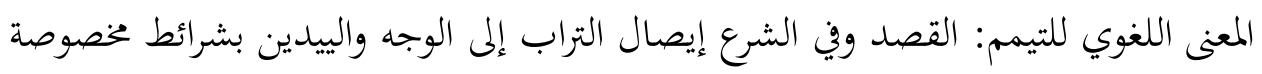

"Etymologically, tayammum is defined as intentional, meanwhile according to syara', tayammum is stroking holy dust to face and hands under predetermined conditions. ${ }^{13}$

Sayyid Sabiq in his book, defines tayammum as:

$$
\text { القصد للصعيد لمسح الوجه اليدين بنية استباحة الصلاة ونهوها }
$$

"Intentional use of soil to stroke face and hands for performing salat and other prayers. ${ }^{143}$

Then, a question is raised when a Muslim who is a healthcare worker in a hospital and other sites cannot perform wudu or tayammum as the requirement to perform salat because of his obligations to treat those who are infected by a virus, such as COVID-19. This article will discuss the rules to perform salat without wudu or tayammum for COVID-19 healthcare workers based on the perspectives of four fiqh madhhab.

\section{Research method}

The authors use a qualitative method which is frequently employed as the basis of research assumptions in the fields of Shari'a, social sciences, and humanities. Qualitative research is aimed at knowledge construction through discovery and understanding of situations, both textually and contextually. Qualitative research seeks to investigate a social phenomenon arising from the cause of a case, including values and norms of society, and even problems that arise within human life. Using the qualitative method, the authors try to make a constructive, complex, detailed report, analyzing the word from the perspective of several respondents and exploratory studies on natural situations. ${ }^{15}$

Scientific research categorized as library research plays a crucial rule in the entire set of research methodologies. Literature research has several objectives, such as: linking research with various existing literature that fits the research theme, informing the audience about the results of the other research conducted at the same time with similar

${ }^{13}$ Al Ramli, Nihayatul Muhtaj ila Syarhil Minhaj, jilid 1, 263.

${ }^{14}$ Sayyid Sabiq, Fiqih al-Sunnah, (Kaherah: Dar al-Hadits, cet. 1, 2004), 56.

${ }^{15}$ Iskandar, Metodologi Penelitian Kualitatif, (Jakarta: Gaung Persada, 2009), 11. 
topics, and filling the gaps of previous studies. ${ }^{16}$ The literature review is intended to summarize and interpret theories and concepts which is related to ongoing research. ${ }^{17}$

In relation to the ongoing research "Salat Without Wudu and Tayammum Performed by COVID-19 Healthcare workers: The Analysis of Fiqh Madhhab Comparison", the writer uses literature method, and this discussion is expected to become a more constructive discipline study than previous study or research.

\section{The Importance of Salat Establishment}

For every Muslim that meets the requirements (Mukallaf), salat is an obligation that should be performed according to rules from Al-Qur'an and Sunnah. Salat is a medium of spiritual communication between His Muslim servant and The Creator without a veil. This communication is a form of a dialogue between the spirit that occupies the body and The Sublime. In essence, His devout servants who only perform salat in a careless manner to only fulfil their obligations could never form measured, balanced, and harmonized identity with themselves, their environment and their God. This is because salat has a special place in Islam, where Allah SWT praises His devout servants who maintain their salat, especially five daily prayers. ${ }^{18}$ His Words:

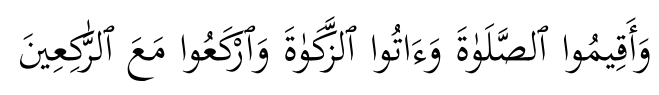

"And establish prayer and give zakah and bow with those who bow [in worship and obedience]." (QS: al-Baqarah: 43)

And His Revelation:

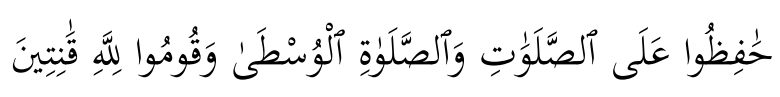

"Maintain with care (your) prayer and (maintain) the middle prayer and stand before Allah (in your prayer), devoutly obedient." (QS: al-Baqarah: 283)

And Hadith of Prophet Muhammad SAW:

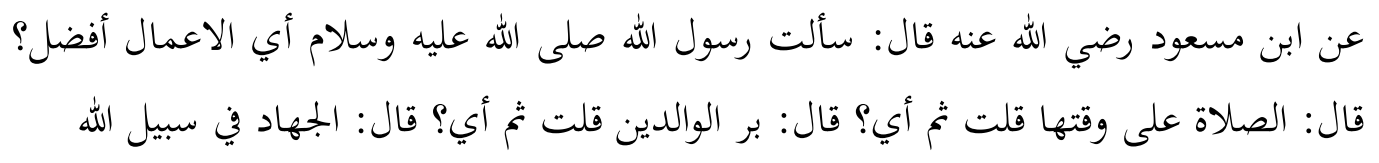

"From ibn Mas'ud, he said: I asked the Prophet "Which deed is the dearest to Allah?" He replied, "To offer the prayers at their early stated fixed times." I asked, "What is the next (in goodness)?" He replied, "To be good and dutiful to your parents" I again asked, "What

\footnotetext{
${ }^{16}$ Creswell John W., Research Design: Qualitative, Quantitative, and Mixed Methods Approaches, 3th, terjemahan Achmad Fawaid, (Yogyakarta: 2010), 40.

17 Gary Anderson and Nancy Arsenault, Fundamentals of Educational Research, 2nd Edition, (Philadelphia: The Falmer Press, 1998), 83.

18 Sri Jumini, Chakimatul Munawaroh, Analisis Vektor Dalam Gerakan Shalat Terhadap Kesehatan, Journal:: SPEKTRA, Vol. IV, No. 2 (September 2018), 124-125.
} 
is the next (in goodness)?" He replied, 'To participate in Jihad (religious fighting) in Allah's cause."19

Based on the Quran verses and hadith above, it can be understood that salat is an obligatory prayer for every devout Muslim in their daily lives in accordance with the defined conditions. For every Muslim, salat is very important because salat determines the establishment of Islam in oneself like Prophet Muhammad SAW said:

$$
\text { الصلاة عماد الدين فمن أقامها فقد اقام الدين ومن تركها فقد هدم الدين }
$$

"Salat is the pillar of Islam, those who perform salat have established their religion, and those who don't perform salat have demolished their religion."20

Salat is the first duty in Islam after declaring Shahada. Salat is obliged by Islam based on His Commands for men, women, slaves, freed, poor, rich, mukmin, Musafir, healthy and sick. Therefore, this obligatory prayer is not void for everyone that qualifies as a mukallaf (baligh, etc.), in whatever condition. This is obviously different from other rituals such as zakat and hajj that are obligated with several requirements and conditions, performed at a certain time, and with prescribed limitations. ${ }^{21}$ Therefore, Quran heavily emphasizes the importance of salat. Laziness and reluctance to perform salat is a sign of negligence and deprivation of faith. ${ }^{22}$

Salat plays an important role in humankind, especially Muslims, in achieving world and afterlife happiness. In other words, salat is a massive ritual to get closer to The Creator, Allah SWT. Salat is a religious obligation for His devout Muslim servants at day, noon, afternoon and evening until the end of their lives. ${ }^{23}$ His Revelation in alQur'an:

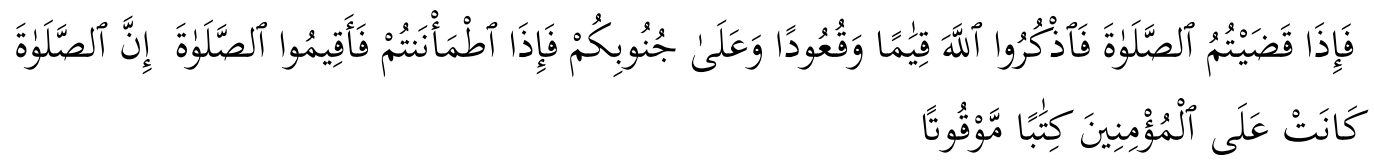

"And when you have completed the prayer, remember Allah standing, sitting, or [lying] on your sides. Nevertheless, when you become secure, re-establish [regular] prayer. Indeed, prayer has been decreed upon the believers a decree of specified times." (QS: anNisa: 103)

\footnotetext{
${ }^{19}$ Muhammad ibn Ismail al-Bukhari, Shahih Al-Bukhari, (Beirut: Dar ibn Katsir, cet. 1, 2002), kitab: mawaaqitu al shalat, bab: fadli al shalat liwaqtiha, hadits no 527, 138.

${ }^{20}$ Isma'il bin Muhammad al-'Ajluni al-Jarrahi, Kashfal Khafa' Wamuzil al-Ilbas 'Amma Ishtahara min al-Hadith 'ala al-Sinatil Nas, (Beirut: Muassasah al-Risalah, cet. 4,1985), jilid 2, 39-40. https://www.almeshkat.net/book/4141.

${ }^{21}$ Hari Kohari Permasandi, Peranan Pembimbing Agama Dalam Meningkatkan Ibadah Shalat Pada Lansia di Balai Perlindungan Sosial Dinas Sosial Provinsi Banten, Skripi: Universitas Islam Negeri Hiayatullah Jakarta, 2011, 3.

${ }^{22}$ Sudirman Tebba, Nikmatnya Shalat Jamaah, (Jakarta: Bulan Bintang, cet, 1, 2002), 9.

23 Noraini Junoh, Nor Asmira Mat Jusoh, Falsafah Ibadah Solat berdasarkan al-sunnah: analisis pandangan shah wali allah al-dihlawi, Journal: SeFPIA, Special Edition, 2018, 140. http://jfatwa.usim.edu.my/index.php/jfatwa/article/view/143/117.
} 


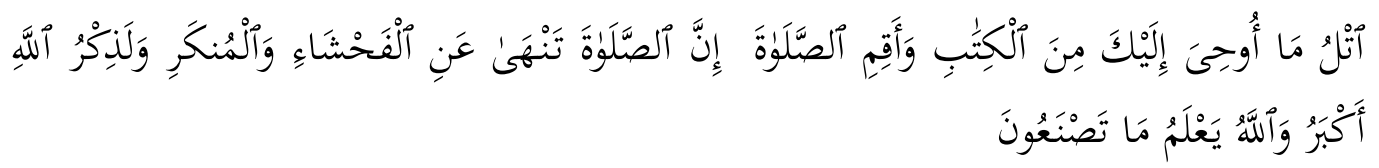

"Recite, [O Muhammad], what has been revealed to you of the Book and establish prayer. Indeed, prayer prohibits immorality and wrongdoing, and the remembrance of Allah is greater. And Allah knows that which you do." (QS: al-Ankabut: 45)

Therefore, the verses above show the importance of performing salat that has been obliged by Allah SWT to His devout Muslim servants.

\section{Salat Without Wudu and Tayammum}

Salat is not valid unless performed under the prescribed conditions. Salat performed by Muslim who do not follow the conditions of valid salat is not valid and will not be accepted. One of the conditions for valid salat is wudu. According to Ustad Cecep Suherman, the perfection in doing wudu is something that should be noticed before praying. ${ }^{24}$

Islam highly values wudu, even obligates it if it is done to establish salat. Salat cannot be performed without ablution or wudu beforehand. This corresponds with the obligation of wudu that was applied along with the command of salat to all His devout Muslim servants. ${ }^{25}$ The Messenger of Allah said:

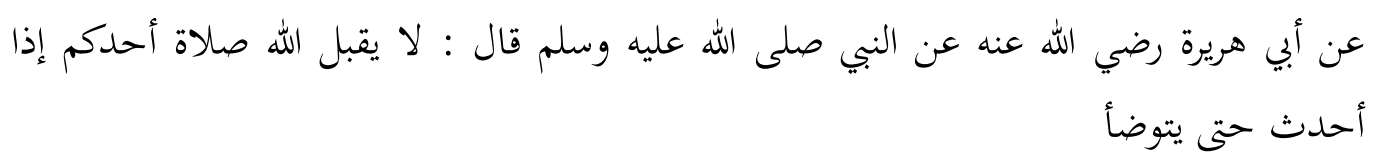

"From Abu Hurairah Radhiyallahu Anhu, he said, "the Prophet said: "Allah does not accept the prayer of one of you when he commits Hadath, until he performs Wudu."26

$$
\text { مفتاح الصلاة الطهور، وتحيمها التكبير، وتحليلها التسليم }
$$

"The key to Salat is the purification, its Tahrlm is the Takblr, and its Tahlil is the Taslim."27

Islam is so beautiful and full of blessings and ease have given by Allah SWT to His servants. Allah SWT wants easiness for His servants so they will not be neglectful in their prayers. Therefore, He gave rukhsah (concession) in the form of tayammum. Tayammum is an ablution method whose nature is dharuri, which means it is permittable

24 Irwan Kelana, Syarat Sah Shalat, Jangan Remehkan Wudhu, Republika.co.id, https://khazanah.republika.co.id/berita/pwb6za374/syarat-sah-shalat-jangan-remehkan-wudhu. Accessed on 05 April 2020, 22:49pm.

${ }^{25}$ Qurrotul Aien Bt Fatah Yasin, Mukjizat Wuduk Ke Atas Rohani dan Jasmani Manusia, International Journal on Quranic Research, Vol. 2, No. 2 (2012), 68.

${ }^{26}$ Abul Husayn Muslim ibn al-Hajjaj Qushayri al-Nisaburi, Shahih Muslim, (Beirut: Dar al-Fikr, cet. 1, 2003), kitab: thaharah, bab: wujub al-thaharah lil al-shalat, hadits no 425, 134.

27 Abu Da'ud Sulayman ibn Ash 'ath al-Azadi al-Sijistani, Sunan Abu Daud, Muhaqqid: Syu'aib alArnuth, (Damaskus: Dar al-Risalah al-Alamiah, cet. 1, 2009), kitab: al-thaharah, bab: fardhu al-wudhu, hadis no 61 , jilid 1, 45 . 
if the water is not available or cannot be used because of limitations (udzur) so one should purify through tayammum.28

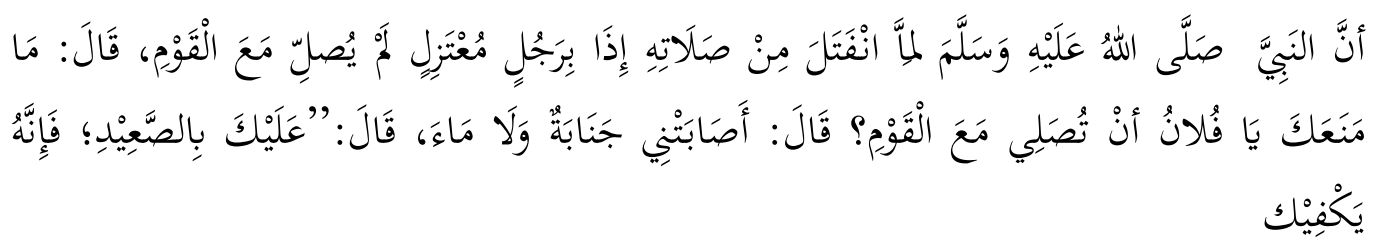

"After The Prophet finished from the prayer, he saw a man sitting aloof who had not prayed with the people. He asked, "What has prevented you from praying with us?" He replied, "I am Junub and there is no water. " The Prophet said, "Perform Tayammum with (clean) earth and that is sufficient for you." 29

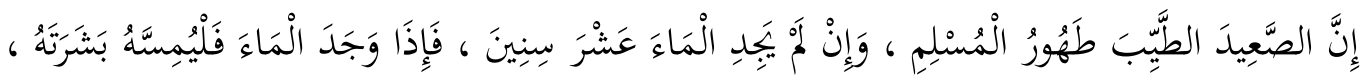

$$
\begin{aligned}
& \text { فَاِنَّ ذَلِكَ خَِِّ }
\end{aligned}
$$

"Clean earth (pure) is a means for ablution for Muslim, even for ten years (he does not find water); but when you find water, you should make it touch your skin, for that is better." 30

Therefore, it can be concluded that a good ablution with wudu or tayammum is one of the conditions for valid salat. However, what if a Muslim performs salat under the event of ongoing virus pandemic (COVID-19) where the healthcare workers have to fight this virus and are experienced by many countries, including Indonesia. ${ }^{31}$

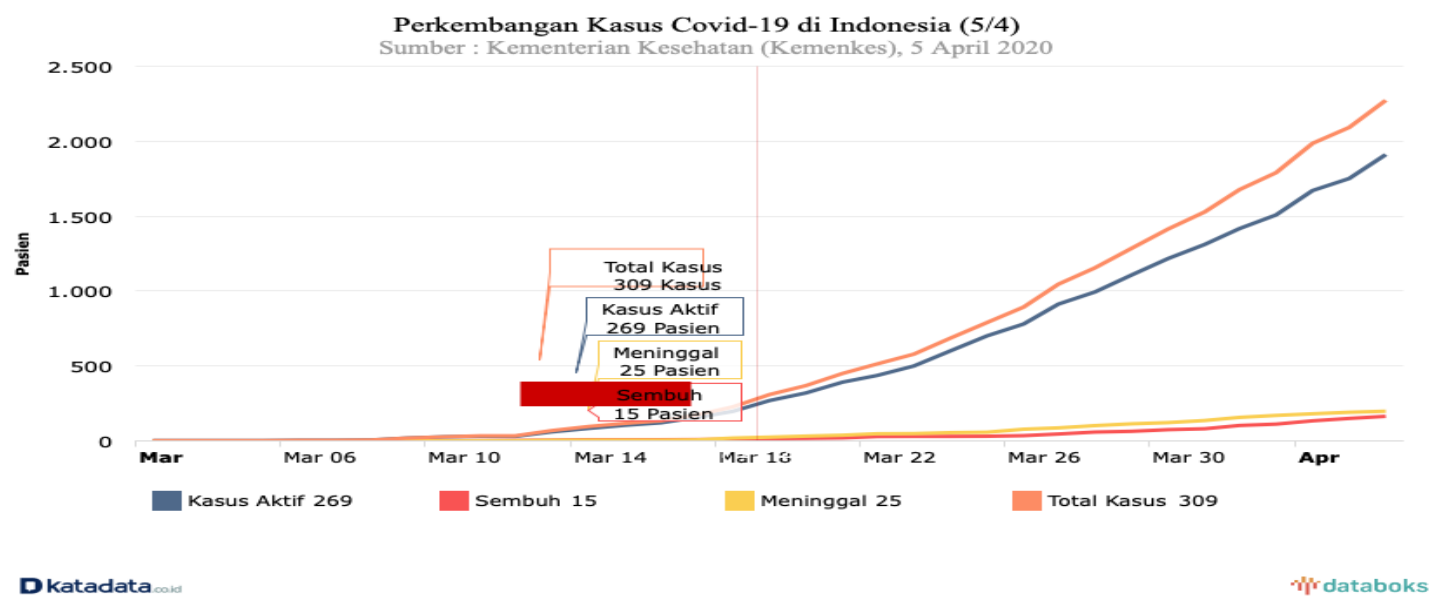

${ }^{28}$ Abu Zakaria Mohiuddin Yahya Ibn Sharaf al-Nawawi, al-Majmou' sharh al-Muhathab, (Riyadh: Dar 'Alim al-Kutub, 2003), jilid 2, 165.

${ }^{29}$ Muhammad ibn Ismail al-Bukhari, Shahih Al-Bukhari, kitab: al-tayammum, bab: al-sha'id altayyib, hadits no 344, 94-95.

${ }^{30}$ Abu Da'ud, Sunan Abu Daud, kitab: al-thaharah, bab: al-junub yatayammum, hadits no 332, jilid $1,246$.

${ }^{31}$ Saefudin Achmad, Wacana Shalat Tanpa Wudhu dan Tayammum bagi Petugas Medis yang Menangani COVID-19, RedadksiIndonesia.com:https://redaksiindonesia.com/read/wacana-sholat-tanpa-wudhu-dantayamum-bagi-petugas-medis-yang-menangani-COVID-19.html, accessed on 06 April 2020, 00:51am. 


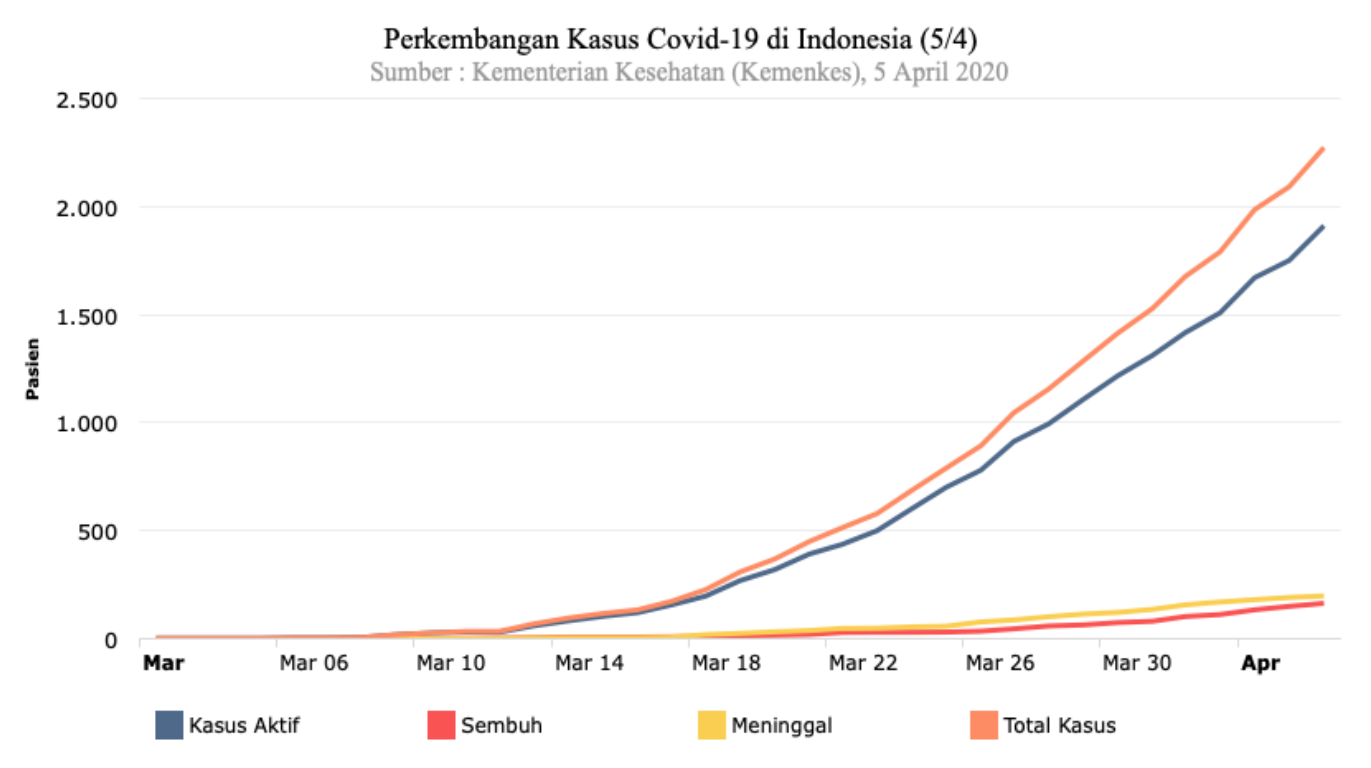

Dkatadata ${ }_{\text {oid }}$

Wrdataboks

The positive Corona or COVID-19 cases in Indonesia were first confirmed on Monday, 2 March 2020 and broadcasted by President Joko Widodo. Since then, the number of positive cases keeps increasing daily. There are patients who are passed away, many are negatives and recovered. Example, on the day this article is made, which is Sunday, 05 April 2020, the number of cases has reached 2.273 people, 181 higher than the day before and will keep increasing the days after. ${ }^{32}$

The same data also shows that 1.911 COVID-19 positive patients are currently undergoing treatment. This number is 84,07 per cent of total corona cases in the country. Meanwhile, the number of recovered COVID-19 positive patients increases to 164 people. With the addition of 14 recovered patients today, the percentage of recovery rate in Indonesia is 7,21 per cent. Unfortunately, the number of COVID-19 patient death in Indonesia keeps increasing, 198 people on Monday, 05 April 2020.33

32 Muchmad Nafi, Gelombang Virus Corona di Antara Minimnya Fasilitas dan Tenaga Medis, katadata.co.id: https://katadata.co.id/berita/2020/04/06/gelombang-virus-corona-di-antara-minimnyafasilitas-dan-tenaga-medis. Accessed on 05 April 2020, 17:12 pm.

33 Addi M Idhom, Update Corona 5 April di Indonesia: Sebaran COVID-19 di 32 Provinsi, tirto.id: https://tirto.id/update-corona-5-april-di-indonesia-sebaran-COVID-19-di-32-provinsi-eK7p. accessed on 05 April 2020, 17:20pm. 


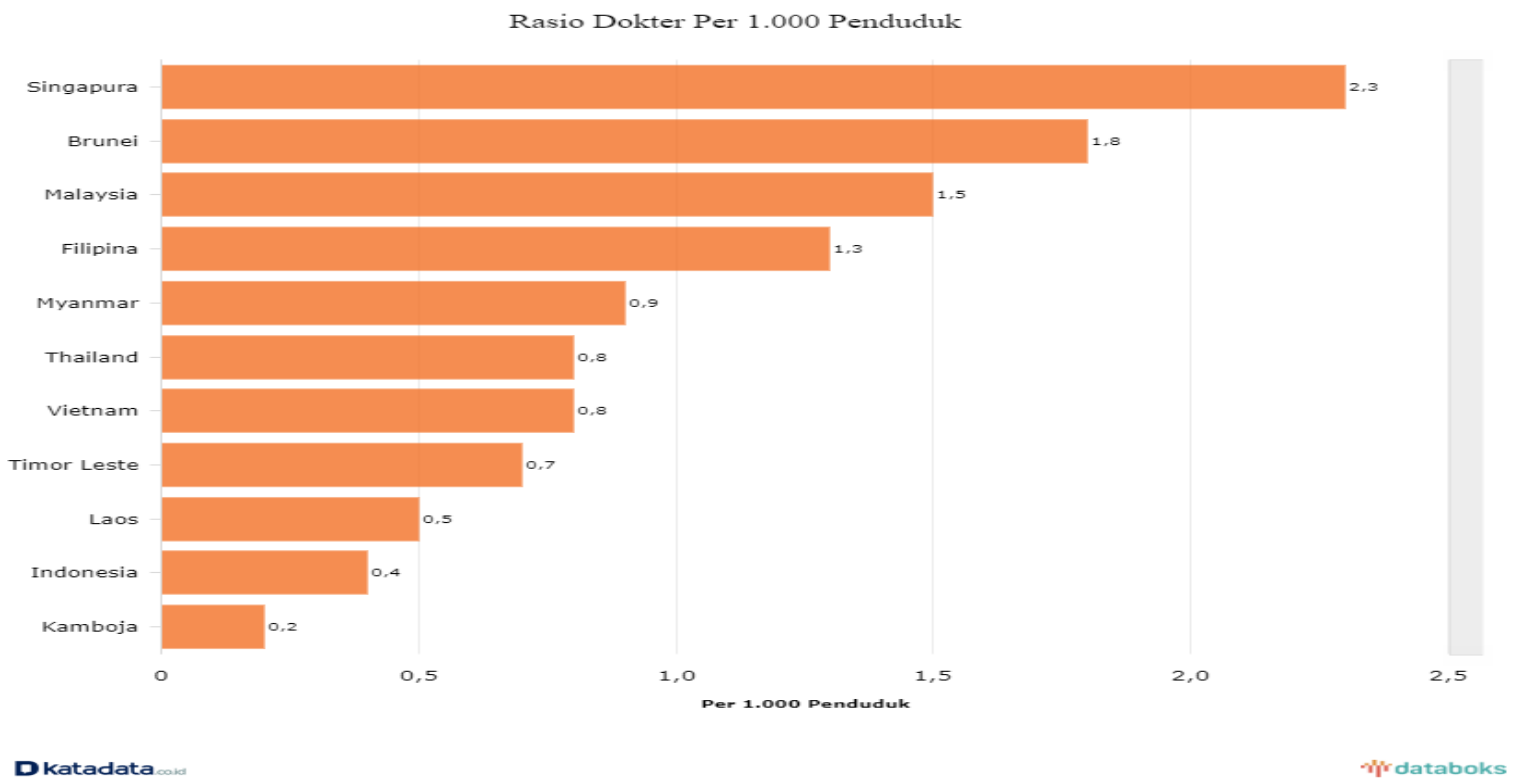

Meanwhile, the number of doctors in Indonesia is the second-lowest in Southeast Asia, which 0,4 doctor per 1.000 people. It means only four doctors are capable of serving 10.000 people in Indonesia. This number is lower if compared to Singapura that has two doctors per 1.000 people. The number of another healthcare worker is also limited. The availability of nurses and midwife in Indonesia is placed on the worst position among other countries. The ratio of nurses per 1.000 people is 2,1 , which means two nurses to serve 1.000 people. ${ }^{34}$

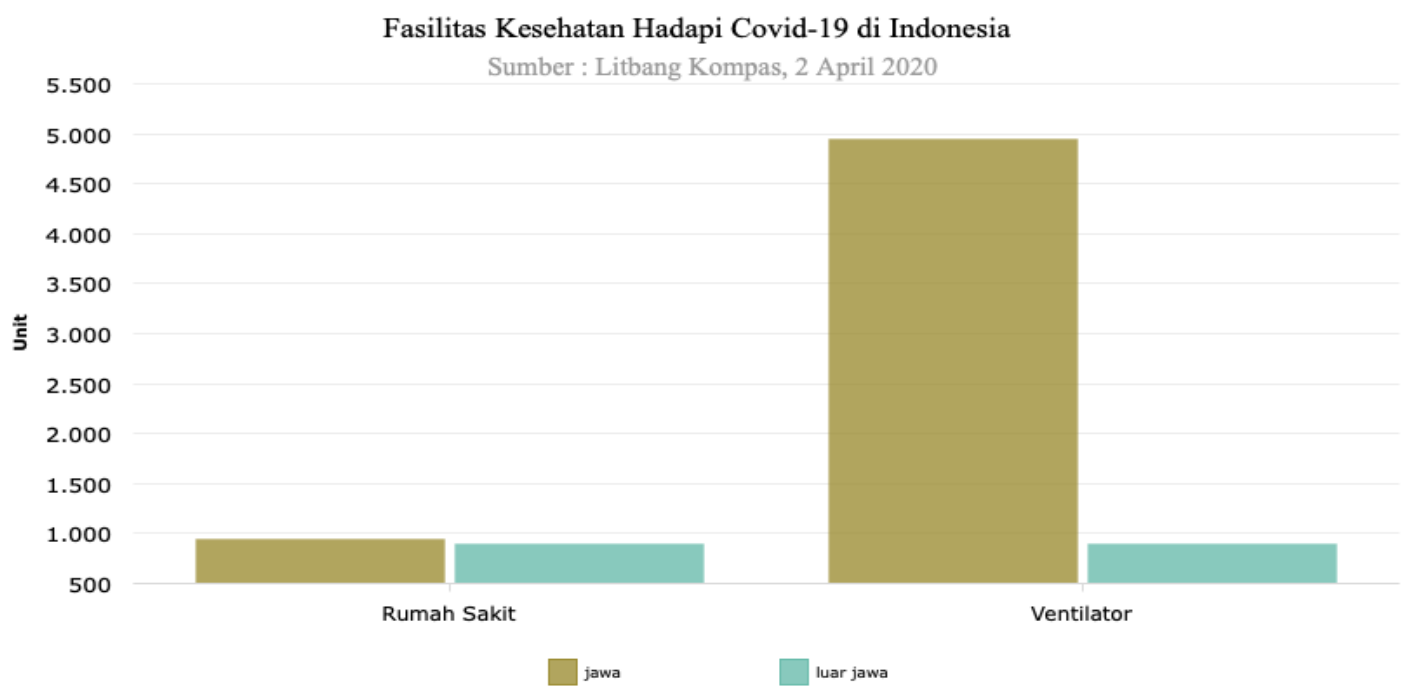

Dkatadata ovid

${ }^{34}$ Muchmad Nafi, Gelombang Virus Corona di Antara Minimnya Fasilitas dan Tenaga Medis. 


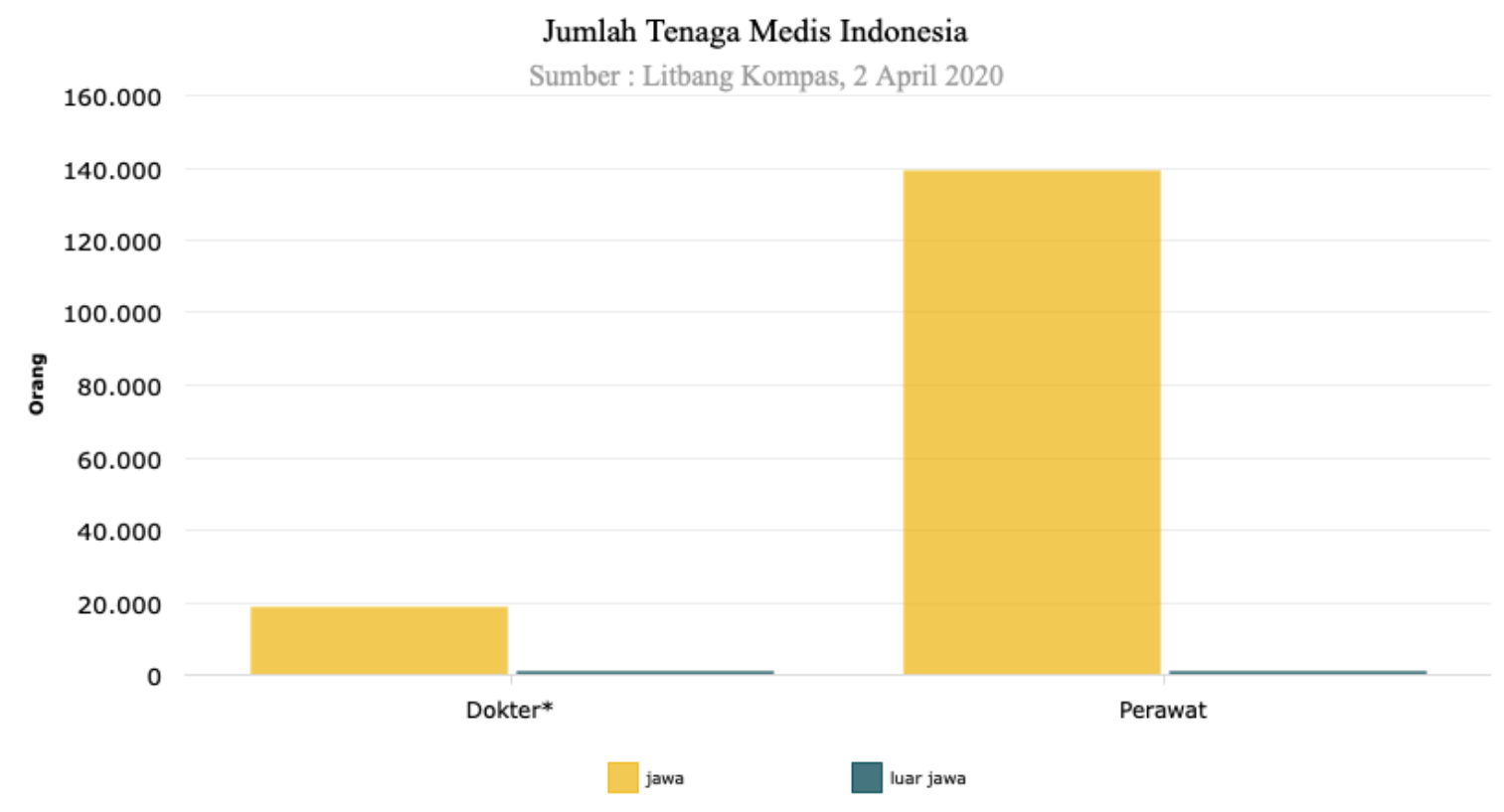

Besides, the number of medical workers in the treatment of coronavirus (COVID19) in Indonesia remains unbalanced. The majority of medical personnel are in Java, approximately $98.9 \%$. Doctors and nurses who were in service outside Java were only $1.1 \%$ or 1,787 people. The number of doctors in Indonesia is 19,649 , but only 893 people or $4.5 \%$ of them serve outside Java. The remaining 18,756 people equal to $95.5 \%$ are based in Java. Inequality also occurs for nurses who are in quantity more with a total of 140,071 people. Nurses outside Java are only 894 people or $0.6 \%$ so that almost all nurses in Indonesia are employed in Java, namely $99.4 \%$ or 139,177 people. ${ }^{35}$

Also, in the face of the COVID-19 pandemic, Indonesia has 1,827 hospitals and 5,834 ventilators. However, its distribution remains concentrated in Java. Of the total hospitals, there are 936 units are in Java (51\%), while outside Java only 891 units (49\%). The number of ventilators in Java reached 4,942 units, although outside of Java only 892 units. 36

So, based on the data above it is clear that the responsibilities and roles held by healthcare workers in managing the COVID-19 pandemic are not easy. Nevertheless, in fulfilling their responsibilities as a health worker, those who are Muslims should not abandon their responsibility as His Servant to keep performing the five daily salat even

35 Yosepha Pusparisa, Ketimpangan Jumlah Tenaga Medis RI dalam Penanganan COVID-19, https://databoks.katadata.co.id/datapublish/2020/04/08/timpangnya-tenaga-medis-penanganan-COVID19?fbclid=iwar2bqhedigd0ivr445nzwdlrclmrjovtmlkfiaxpsjb3y9te2kne8jhch3w. accessed on 12 April 2020, 19:38 pm.

36 Yosepha Pusparisa, Hadapi COVID-19, Fasilitas Kesehatan Masih Terpusat di Jawa, https:/databoks.katadata.co.id/datapublish/2020/04/08/hadapi-COVID-19-fasilitas-kesehatan-masihterpusat-di-jawa?fbclid=iwar1owvyi4ri1 riszac3jtsrkkacvnxp5g72ett1jlb3kt1n3a2fgpcmezk0, accessed on 12 April 2020, 19:54pm. 
though they have to wear PPE (Personal Protective Equipment) at all times. This leads them to perform salat without wudu or tayammum due to the threatening risk and danger of pulling off their PPE. Taking off PPE would allow them more likely to increase the chance to get infected the COVID-19. ${ }^{37}$

\section{Fatwa of Indonesian Ulema Council (MUI) Regarding Prayers without Wudhu and Tayammum for COVID-19 Medical Team}

In Indonesia, this issue has been discussed by the Indonesian Ulema Council (MUI). Indonesian Ulema Council recently issued Fatwa No. 17 the Year 2020: Salat Guidelines for Healthcare Worker Who Wears Personal Protective Equipment (PPE) When Treating and Managing COVID-19 Patients. In its fatwa, the Indonesian Ulema Council implemented eleven items related to performing salat for COVID-19 workers: ${ }^{38}$

1. Muslim healthcare workers who are treating COVID-19 patients while wearing APD are still obliged to perform fard salat under all conditions in accordance with their capability.

2. If the time for salat comes after their shift is over or before their shift starts, they are obliged to perform fard salat according to the rules.

3. If their shift starts before the time of zuhr or maghrib and ends during the time for asr or isha, then they may perform salat with jama' ta'khir.

4. If their shift starts during the time of zuhr or maghrib and they cannot perform salat during asr or isha, they may perform salat with jama'taqdim.

5. If their shift is between the time span of two salat that can be combined (jam'u) (zuhr with asr and maghrib with isha), they may perform salat in Jam' bayn asSalaatayn.

6. If their shift is during the time for salat and they are in the state of tahara, they may perform salat at the prescribed time while wearing PPE.

7. If their conditions complicate wudu, they may perform tayammum to pray.

8. If they are in the state of hadas and cannot perform ablution (wudu or tayammum), they may perform salat under their current condition (faqid althahurain) and are not obliged to repeat their salat (i'adatu al-shalah).

9. If their PPE is in contact with najis and it is not possible to take off and purify it, they may perform salat in unclean condition and are obliged to repeat salat (i'adatu al-shalah) after finishing their duty.

\footnotetext{
${ }^{37}$ Agung Pribadi, Begini Cara Sholat Tenaga Medis Perawat Pasien Corona Berdasarkan Fatwa MUI, kompas.tv: https://www.kompas.tv/article/73272/begini-aturan-salat-bagi-tenaga-medis-yang-tengahmerawat-pasien-corona, accessed on 8 April 2020, 11:35am.

$38 \quad$ https://mui.or.id/wp-content/uploads/2020/03/fatwa-mui-nomor-17-tahun-2020-tentangshalatnya-tenaga-kesehatan-COVID-19.pdf, accessed on 8 April 2020, 11:04am.
} 
10. Healthcare supervisor is obliged to manage the shifts for Muslim healthcare workers and consider the salat times for religious obligation and self-safety.

11. Healthcare workers regard this fatwa as a guideline to perform salat while keep maintaining the self-safety aspects.

\section{Shalat Without Wudhu dan Tayammum Based on Four Madhab Fiqh}

The discussion regarding salat without wudu and tayammum is not a new topic in fiqh. This condition is called faqidu ath-thahurain, which means people who lost two purification means, water for wudu and dust for tayammum. In fiqh literature, almawsu'ah al-fighiyyah book expands the definition the term of faqidu ath-thahurain:

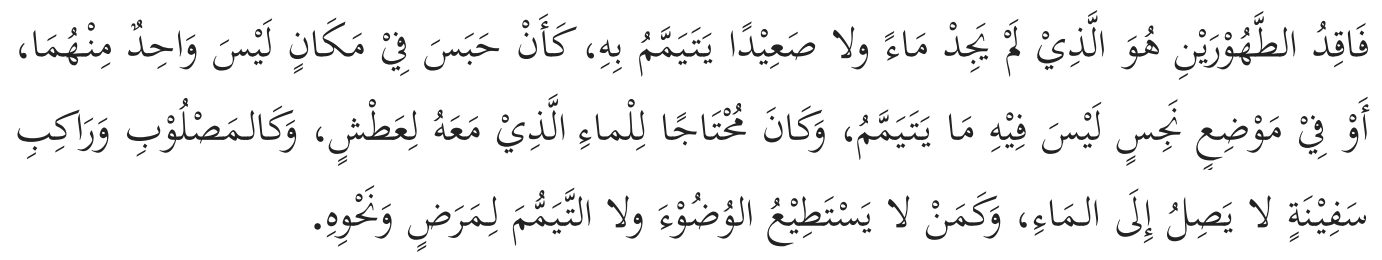

"Faqidu ath-thahurain is defined as people who cannot find water or dust used for tayammum, such as if he is imprisoned in a place that does not have one of those two items (water and dust), if he is imprisoned in a najis place without dust for tayammum, if he needs the water he carries for his thirst, if he is crucified or boat passenger who cannot reach water, if he cannot perform wudu and tayammum because of sickness, etc." 39

From the text above it can be concluded that healthcare workers that use PPE can be categorized as faqidu ath-thahurain because they fall into the last criteria, which is inability to perform wudu or tayammum. Their PPE is disposable and used for one shift, which is six to seven hours. Even if they remove it to perform wudu or tayammum, they have to wear new PPE and repeat the initial procedure, such as the PPE must be sprayed with antiseptic and sterilized with an autoclave. ${ }^{40}$

This is obviously very inconvenient for them, so this condition is categorized as udzur syar'i, a condition that forbids them to perform wudu or tayammum. What are the rules in performing salat in faqidu ath-thahurain condition according to the perspectives of four figh madhhab and how does one practice them? The fuqaha of four fiqh madhhab fiqh (Hanafi, Syafi'i, Hanbali dan Maliki) have different perspectives regarding the salat of faqidu ath-thahurain..$^{41}$ There are at least four viewpoints regarding the faqidu ath-thahurain according to four fiqh madhhab:

1. It is obliged to perform salat if one's incapability is categorized as contact with najis, but it is obliged to repeat the prayer (i'adatu al-shalah). This is al-Qaul alJadid of Imam Syafi'I. This viewpoint also is the viewpoint of Imam Malik, Imam

${ }^{39}$ Kementrian Wakaf Kuwait, al-Mausu ah al-Fiqhiyyah al-Kuwaitiyyah, (Kuwait: Dar as-Salasil, cet. 2, 1988), jilid 14, 273.

40 https://www.goriau.com/berita/baca/fatwa-mui-petugas-medis-pakai-apd-boleh-shalat-tanpabersuci-dan-wudhu.html, accessed on 8 April 2020, 14:01pm.

${ }^{41}$ Kementrian Wakaf Kuwait, al-Mausu `ah al-Fiqhiyyah al-Kuwaitiyyah, jilid 27, 127. 
Ahmad and Hanafi madhhab. The proposition is to fulfil obligation at that time (li hurmati al-waqti). ${ }^{42}$ His Words:

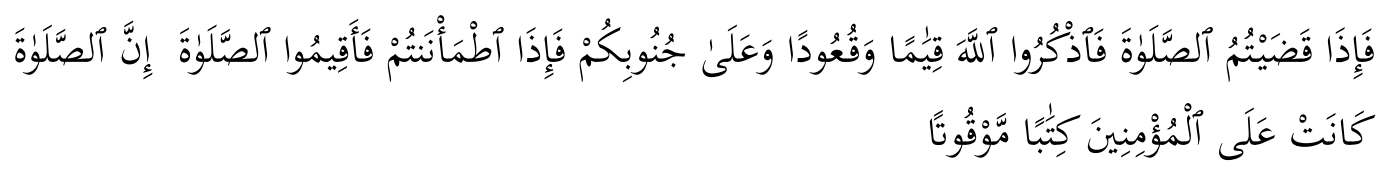

"And when you have completed the prayer, remember Allah standing, sitting, or [lying] on your sides. But when you become secure, re-establish [regular] prayer. Indeed, prayer has been decreed upon the believers a decree of specified times." (QS: an-Nisa: 103)

2. One does not need to perform salat and repeat it (i'adatu al-shalah) if there is no difficulty because ablution with water or dust is one of the obligations for performing salat. This is also the opinion of Imam Malik and some of Zhahiriyah madhhab. ${ }^{43}$

3. It is sunnah to perform salat and it is wajib to qada after there is no masyaqqah (difficulty). This is the opinion of at-Tsauri al-Awza'I, Abu Hanifah, and defines as qaul qadim as-Syafi'i. ${ }^{44}$

4. It is obliged to perform salat and not obliged to repeat the prayer (i'adatu alshalah). This is the viewpoint chosen by imam al-Nawawi, imam al-Muzzani, alBukhari, and it is a strong opinion in Malik and Hanbali madhhab and has more substantial argumentation..$^{45}$ The hujjah is on the hadith narrated by al-Bukhari in his Shahih book from Aisyah RA:

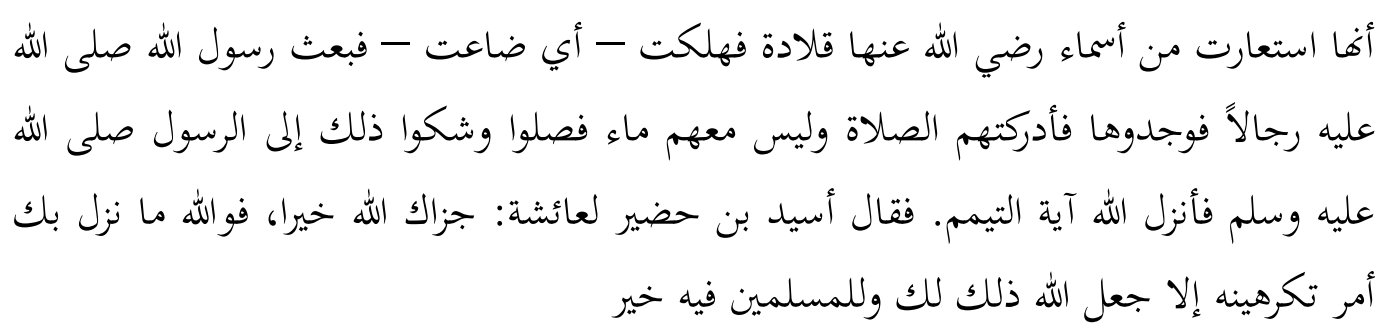

"Aisha said, "I borrowed a necklace from Asma' and it was lost. So Allah's Messenger sent a man to search for it and he found it. Then the time of the prayer became due and there was no water. They prayed (without ablution) and informed Allah's Messenger about it, so the verse of Tayammum was revealed." Usaid bin Hudair said to `Aisha, "May Allah reward you. By Allah, whenever anything happened which you did not like, Allah brought good for you and for the Muslims in that."46

Based on the considerations above, it can be understood that healthcare workers that use PPE in the midst of COVID-19 pandemic is permitted to choose the opinion with stronger proposition and hujjah, which is the obligation to perform salah even in the

\footnotetext{
42 Ibid., jilid 31, 193.

${ }^{43}$ Ibid., jilid 31, 193.

${ }^{44}$ Al-Ramli, Nihayatul Muhtaj ila Syarhil Minhaj, jilid 1, 318-319.

${ }^{45}$ Abu Zakaria Mohiuddin Yahya Ibn Sharaf al-Nawawi, al-Minhaj Fi Sharah Sahih Muslim bin Hajjaj, (Suriah: Muassasah Qurtuba, cet. 2, 1994), jilid 4, 80.

${ }^{46}$ Muhammad ibn Ismail al-Bukhari, Shahih Al-Bukhari, kitab: at-tayammum, bab: idza lam yajid maa wala thurab, hadits no 336, 93.
} 
condition of faqidu ath-thahurain and it is not obliged to repeat (i'adatu al-shalah) or qada. However, if the PPE worn by them has contact with najis or becomes najis, such as if they are unable to hold urination and other condition, they are still obliged to pray and repeat the salah when they no longer wear the PPE. All these facilitations are the reflection of the principle of concession (taysir) in the implementation of Islamic law as stated in the revelation of Allah SWT:

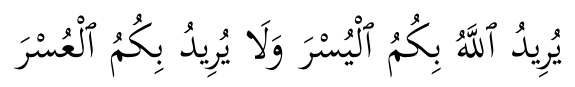

"Allah intends ease for you and does not intend hardship for you" (QS: al-Baqarah: 185)

$$
\text { وَمَا جَعَلَ عَلَيْكُمْ فِ ألَّدينِ مِنْ حَرَجِ }
$$

"He has not placed upon you in the religion any difficulty." (QS: al-Haj: 78)

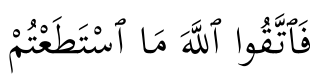

"So fear Allah as much as you are able to." (QS: al-Taghabun: 16)

\section{Combining $\left(\mathrm{Jam}^{\prime} u\right)$ Salat for COVID-19 Healthcare Workers}

Indonesian Ulema Council in its Fatwa No. 17 the Year 2020 declares that it is allowed to combine (jam'u) salat for COVID-19 healthcare workers if: First, if they're in duty before the time of zuhr or maghrib and their shift ends during the time for asr and isha, then they may perform salat with jama' ta'khir. Second, if they're in duty during the time of zuhr or maghrib and cannot perform their asr or isha prayers, they may perform salat with jama' taqdim. Third, if they are on duty during two salat time that can be combined or jam' $u$ (zuhr with asr and maghrib with isha), they may perform salat in $j a m^{\prime} u .^{47}$ The basis for this permission to combine $\left(j a m^{\prime} u\right)$ salat is namely the hadith narrated by Ibn 'Abbas RA.

$$
\text { قيحرج أمته. }
$$

“Ibn 'Abbas reported that the Messenger of Allaah combined (jam'u) the zuhr prayer with the asr prayer and the Maghrib prayer with the 'Isha' prayer in Medina without being in a state of danger or rainfall. And in the hadith transmitted by Waki' (the words are):" I said to Ibn 'Abbas: What prompted him to do that? He said: So that his (Prophet's) Ummah should not be put to (unnecessary) hardship." And in the hadith transmitted by

47 https://mui.or.id/wp-content/uploads/2020/03/Fatwa-MUI-Nomor-17-Tahun-2020-tentangshalatnya-tenaga-kesehatan-COVID-19.pdf. 
Mu'awiya (the words are):" It was said to Ibn 'Abbas: What did he intend thereby? He said he wanted that his Ummah should not be put to unnecessary hardship."48

The hadith above is the basis of ulema in their istinbath al-ahkam to allow combining the salat without being in a journey or in the state of danger or sickness. Ulema who give permission to state the 'illat (cause) for this permission is al-haraj (difficult). As long-ass there is a difficulty, combining salat is allowed even when not all ulema agree with this view, as stated by Imam al-Nawawi in his book Rawdhatu atThalibin:

$$
\begin{aligned}
& \text { المعروف في المذهب أنه لا يجوز الجمع بالمرض ولا الخوف ولا الوحل. وقال جماعة من أصحابنا: } \\
& \text { يجيوز بالمرض والوحل. ممن قاله من أصحابنا: أبو سليمان الخطابي والقاضي حسين، واستحسنه } \\
& \text { الروياني. فعلى هذا يستحب أن يراعي الأرفق بنفسه، فإن كان يُهُمُّم مثلاً في وقت الثانية قدَّمها إلى } \\
& \text { الأولى بالشرائط المتقدمة، وإن كان يُحَمُّ في وقت الأولى أخرها إلى الثانية. }
\end{aligned}
$$

"It is knowledgeable in Syafi'I madhhab that one should not combine (jam'u) salat because of sickness, in state of danger, or facing hindrance because of the muddy road (hence difficulties in walking). Several Syafi'I madhhab stated "It is allowed to combine (jam'u) salat for aforementioned sick and late people. Those who held this view: Abu Sulaiman al-Khattabi, al-Qadhi Husain. Ar-Ruyani leaned positively on this view. Therefore, based on these views, it is recommended to consider the best condition for one. Therefore, if fever starts on the time of second salat (asr or isha), combine (jam'u) them with the described preconditions (jama' taqdim). If fever starts on the time of first salat (dzur or maghrib), combine (jam'u) them based on jama' ta'khir. I (Imam Nawawi) said: "opinions that allow the combination because of sickness is the obvious and chosen view." 49

Meanwhile, in Hanbali madhhab, the reasons for the concession to combine $\left(j a m^{\prime} u\right)$ salat are more wider as stated by Wahbah Al-Zuhaili. There are eight reasons that allow one to combine $\left(\mathrm{jam}^{\prime} u\right)$ salah. One of the reasons is a limitation and those who are involved in an important matter that cannot be abandoned and will cause harm if done otherwise. ${ }^{50}$

\section{Conclusion}

Based on the descriptions above, the writer argues that sick people are allowed to combine $\left(\mathrm{jam}^{\prime} u\right)$ salah, especially for the COVID-19 healthcare workers that wear PPE, therefore making it difficult to do ablution (wudu or tayammum) or taking the time to pray. If the number of patients is too high, these conditions are clearly udzur. Udzur

${ }^{48}$ Muslim, Shahih Muslim, kitab: shalah al-musafirin wa qashriha, bab: al-jam'u baina al-shalataini fi al-hadhar, hadits no 705, 324.

49 Muhyiddin Abu Zakariyya Yahya bin Syaraf al-Nawawi, Rawdhah al-Thalibin wa 'Umdah alMuftin, (Beirut: Dar al-Kutub al-Ilmiyah, cet. 4, 2013), kitab: shalah al-musafir, bab: al-jam'u daina alshalataini, jilid 1, 503.

${ }^{50}$ Wahbah Az-Zuhaili, al-Fiqh al-Islamii Wa Adillatuhu, (Suriah: Dar al-Fikr, cet. 2, 1985), Jilid 2, 357-358 
allows them to keep performing five daily salat either with ablution (wudu and tayammum) or without ablution (faqidu ath-thahurain). This udzur also allows them to do jam' $u$ salat because COVID-19 healthcare workers treat lives and their duties cannot be abandoned. Therefore, it is more important for them to combine (jam' $u$ ) salat than to intentionally abandon salat. In the end, everyone hopes for this condition to be over. May Allah SWT gives blessing to everyone who has contributed to finding the solution for this COVID-19 problem. This is also a moment for us to pray to Allah SWT to lift this illness whose cure has not been found yet.

\section{References:}

Abdul Rauf al-Minawi, al-Tauqif 'Ala Muhimmat al-Ta'arif, tahqiq: 'Abdul Hamid Shalah Hamdan, (al-Kaherah:'Alim al-Kutub, cet. 1, 1990), 338. https://ia801200.us.archive.org/10/items/tamotaPDF/tamota.pdf.

Abu Da'ud Sulayman ibn Ash ’ath al-Azadi al-Sijistani, Sunan Abu Daud, Muhaqqid: Syu'aib al-Arnuth, (Damaskus: Dar al-Risalah al-Alamiah, cet. 1, 2009), kitab: althaharah, bab: fardhu al-wudhu, hadis no 61, jilid 1, 45 .

Abu Zakaria Mohiuddin Yahya Ibn Sharaf al-Nawawi, al-Majmou' sharh al-Muhathab, (Riyadh: Dar 'Alim al-Kutub, 2003), jilid 2, 165.

Abu Zakaria Mohiuddin Yahya Ibn Sharaf al-Nawawi, al-Minhaj Fi Sharah Sahih Muslim bin Hajjaj, (Suriah: Muassasah Qurtuba, cet. 2, 1994), jilid 4, 80.

Abul Husayn Muslim ibn al-Hajjaj Qushayri al-Nisaburi, Shahih Muslim, (Beirut: Dar alFikr, cet. 1, 2003), kitab: thaharah, bab: wujub al-thaharah lil al-shalat, hadits no $425,134$.

Creswell John W., Research Design: Qualitative, Quantitative, and Mixed Methods Approaches, 3th, terjemahan Achmad Fawaid, Yogyakarta 2010, . 40.

Deden Suparman, Pembelajaran Ibadah Shalat Dalam Perspektif Psikis dan Medis, Journal: ISTEK, Vol. 9, No. 2 (2015), 48.

Gary Anderson, Nancy Arsenault, Fundamentals of Educational Research, 2nd Edition, The Falmer Press, Philadelphia 1998, 83

Hari Kohari Permasandi, Peranan Pembimbing Agama Dalam Meningkatkan Ibadah Shalat Pada Lansia di Balai Perlindungan Sosial Dinas Sosial Provinsi Banten, Skripi: Universitas Islam Negeri Hiayatullah Jakarta, 2011, 3.

Iskandar, Metodologi Penelitian Kualitatif, (Jakarta: Gaung Persada, 2009) cet.1. 11.

Isma'il bin Muhammad al-'Ajluni al-Jarrahi, Kashfal Khafa' Wamuzil al-Ilbas 'Amma Ishtahara min al-Hadith 'ala al-Sinatil Nas, (Beirut: Muassasah al-Risalah, cet. 4,1985), jilid 2, 39-40. https://www.almeshkat.net/book/4141.

Kamus Bahasa Indonesia, Jakarta: Pusat Bahasa Departmen Pendidikan Nasional, cet. Xvi, 2008 1624. https://Journal:-oldi.or.id/public/kbbi.pdf, accessed on 05 April 2020, 23:11pm. 
Kementrian Wakaf Kuwait, al-Mausu ah al-Fiqhiyyah al-Kuwaitiyyah, (Kuwait: Dar asSalasil, cet. 2, 1988), jilid 14, 273.

Lela, Luknawati, Ketenangan: Makna Dawamul Wudhu (Studi Fenomenologi Pada Mahasiswa UIN Raden Fatah Palembang), Journal: PSIKIS, Vol. 1, No, 2 (Desember 2015), 55.

Muhammad bin Abul Abbas Ahmad bin Hamzah bin Syihabuddin al Ramli, Nihayatul Muhtaj ila Syarhil Minhaj, (Beirut: Dar al-Kutub al-Ilmiah, cet. 3, 2003), jilid 1, 358359.

Muhammad bin Ya'qub al-Fairuzabadi, al-Qamus al-Muhith, (Beirut: Muassasah alRisalah, cet. 8, 2005), 55 .

Muhammad ibn Ismail al-Bukhari, Shahih Al-Bukhari, (Beirut: Dar ibn Katsir, cet. 1, 2002), kitab: mawaaqitu al shalat, bab: fadli al shalat liwaqtiha, hadits no 527, 138.

Muhyiddin Abu Zakariyya Yahya bin Syaraf al-Nawawi, Rawdhah al-Thalibin wa 'Umdah al-Muftin, (Beirut: Dar al-Kutub al-Ilmiyah, cet. 4, 2013), kitab: shalah al-musafir, bab: al-jam'u daina al-shalataini, jilid 1, 503.

Noraini Junoh, Nor Asmira Mat Jusoh, Falsafah Ibadah Solat berdasarkan al-sunnah: analisis pandangan shah wali allah al-dihlawi, Journal: SeFPIA, Special Edition, 2018, 140.

Qurrotul Aien Bt Fatah Yasin, Mukjizat Wuduk Ke Atas Rohani dan Jasmani Manusia, International Journal on Quranic Research, Vol. 2, No. 2 (2012), 68.

Rubino, Studi Kolerasi tentang Pemahaman Pentingnya Ibadah Shalat dan Pengamalannya, Journal: Pendidikan Madrasah, Vol. 3, No. 1 (Mei 2008), 199-200.

Sayyid Sabiq, Fiqih al-Sunnah, (Kaherah: Dar al-Hadits, cet. 1, 2004), 56.

Shalil bin Ghanim as-Sadlan, Fiqih Shalat Berjamaah, Jakarta: Pustaka as-Sunnah, cet. 1, 2006, 30.

Sri Jumini, Chakimatul Munawaroh, Analisis Vektor Dalam Gerakan Shalat Terhadap Kesehatan, Journal: SPEKTRA, Vol. IV, No. 2 (September 2018), 124-125.

Sudirman Tebba, Nikmatnya Shalat Jamaah, (Jakarta: Bulan Bintang, cet, 1, 2002), 9.

Wahbah Az-Zuhaili, al-Fiqh al-Islamii Wa Adillatuhu, (Suriah: Dar al-Fikr, cet. 2, 1985), Jilid 2, 357-358.

Zaitun, Siti Habibah, Implementasi Sholat Fardhu Sebagai Sarana Pembentuk Karakter Mahasiswa Universitas Maritim Raja Ali Haji Tanjungpinang, Journal: Pendidikan Agama Islam: Ta'lim, Vol. 11, No. 2 (2013), 154.

\section{Internet Website}

Addi M Idhom, Update Corona 5 April di Indonesia: Sebaran COVID-19 di 32 Provinsi, tirto.id: https://irto.id/update-corona-5-april-di-indonesia-sebaran-COVID-19di-32-provinsi-eK7p. accessed on 05 April 2020, 17:20pm.

Agung Pribadi, Begini Cara Sholat Tenaga Medis Perawat Pasien Corona Berdasarkan Fatwa MUI, kompas.tv: https://www.kompas.tv/article/73272/begini-aturan-salat-bagi- 
tenaga-medis-yang-tengah-merawat-pasien-corona. Accessed on 8 April 2020, 11:35am.

https://mui.or.id/wp-content/uploads/2020/03/Fatwa-MUI-Nomor-17-Tahun-2020tentang-shalatnya-tenaga-kesehatan-COVID-19.pdf, accessed on 8 April 2020, 11:04am.

https://mui.or.id/wp-content/uploads/2020/03/Fatwa-MUI-Nomor-17-Tahun-2020tentang-shalatnya-tenaga-kesehatan-COVID-19.pdf.

https://www.goriau.com/berita/baca/fatwa-mui-petugas-medis-pakai-apd-boleh-shalattanpa-bersuci-dan-wudhu.html, accessed on 8 April 2020, 14:01 pm.

Irwan Kelana, Syarat Sah Shalat, Jangan Remehkan Wudhu, Republika.co.id, https://khazanah.republika.co.id/berita/pwb6za374/syarat-sah-shalat-janganremehkan-wudhu. Accessed on 05 April 2020, 22:49pm.

Muchmad Nafi, Gelombang Virus Corona di Antara Minimnya Fasilitas dan Tenaga Medis, katadata.co.id: https://katadata.co.id/berita/2020/04/06/gelombang-virus-coronadi-antara-minimnya-fasilitas-dan-tenaga-medis. Accessed on 05 April 2020, $17: 12 \mathrm{pm}$.

Saefudin Achmad, Wacana Shalat Tanpa Wudhu dan Tayammum bagi Petugas Medis yang Menangani COVID-19, Redadksilndonesia.com, https://redaksiindonesia.com/read/wacana-sholat-tanpa-wudhu-dan-tayamumbagi-petugas-medis-yang-menangani-COVID-19.html, accessed on 06 April 2020, 00:51am.

Yosepha Pusparisa, Ketimpangan Jumlah Tenaga Medis RI dalam Penanganan COVID-19, https://databoks.katadata.co.id/datapublish/2020/04/08/timpangnya-tenagamedis-penanganan-COVID-

19?fbclid=iwar2bqhedigd0ivr445nzwdlrclmrjovtmlkfiaxpsjb3y9te2kne8jhch3w, accessed on 12 April 2020, 19:38pm.

Yosepha Pusparisa, Hadapi COVID-19, Fasilitas Kesehatan Masih Terpusat di Jawa, https://databoks.katadata.co.id/datapublish/2020/04/08/hadapi-COVID-19fasilitas-kesehatan-masih-terpusat-dijawa?fbclid=iwar1owvyi4ri1riszac3jtsrkkacvnxp5g72ett1jlb3kt1n3a2fgpcmezk0, accessed on 12 April 2020, 19:54pm. 
Hudzaifah Achmad Qotadah

874 - Fakultas Syariah dan Hukum UIN Syarif Hidayatullah Jakarta 